\title{
MicroRNAs: master regulators of drug resistance, stemness, and metastasis
}

\author{
Umar Raza • Jitao David Zhang • Özgür Șahin
}

Received: 4 December 2013 / Revised: 21 January 2014 / Accepted: 23 January 2014 / Published online: 9 February 2014

(C) Springer-Verlag Berlin Heidelberg 2014

\begin{abstract}
MicroRNAs (miRNAs) are 20-22 nucleotides long small non-coding RNAs that regulate gene expression posttranscriptionally. Last decade has witnessed emerging evidences of active roles of miRNAs in tumor development, progression, metastasis, and drug resistance. Many factors contribute to their dysregulation in cancer, such as chromosomal aberrations, differential methylation of their own or host genes' promoters and alterations in miRNA biogenesis pathways. miRNAs have been shown to act as tumor suppressors or oncogenes depending on the targets they regulate and the tissue where they are expressed. Because miRNAs can regulate dozens of genes simultaneously and they can function as tumor suppressors or oncogenes, they have been proposed as promising targets for cancer therapy. In this review, we focus on the role of miRNAs in driving drug resistance and metastasis which are associated with stem cell properties of cancer cells. Furthermore, we discuss systems biology approaches to combine experimental and computational methods to study effects of miRNAs on gene or protein networks regulating these processes. Finally, we describe methods to target oncogenic or replace tumor suppressor miRNAs and current delivery strategies to sensitize refractory
\end{abstract}

Electronic supplementary material The online version of this article (doi:10.1007/s00109-014-1129-2) contains supplementary material, which is available to authorized users.

U. Raza • Ö. Șahin $(\bowtie)$

Department of Molecular Biology and Genetics, Faculty of Science, Bilkent University, 06800, Ankara, Turkey

e-mail: sahinozgur@gmail.com

J. D. Zhang

Bioinformatics and Exploratory Data Analysis, Pharmaceutical Research and Early Development (pRED), F. Hoffmann-La Roche AG, 4070 Basel, Switzerland cells and to prevent metastasis. A holistic understanding of miRNAs' functions in drug resistance and metastasis, which are major causes of cancer-related deaths, and the development of novel strategies to target them efficiently will pave the way towards better translation of miRNAs into clinics and management of cancer therapy.

Keywords MicroRNAs · Drug resistance $\cdot$ Stemness $\cdot$ Epithelial-mesenchymal transition $\cdot$ Metastasis $\cdot$ miRNAprotein interaction networks $\cdot$ Systems biomedicine

\section{Introduction}

miRNAs are a large family of small regulatory RNAs, acting mostly in post-transcriptional gene silencing. They are 20-22 nucleotides long and recognize their target mRNAs by complementary base pairing. They control gene expression by mRNA cleavage, mRNA destabilization, or inhibition of translation [1]. Almost half of miRNAs reside in clusters and transcribed as polycistronic precursor miRNAs [2]. Other miRNAs, located in intergenic regions, are transcribed by their own promoters, and those present in intronic regions are likely under the control of the host genes' promoters [3]. Currently, it has been reported that there are around 2,600 unique mature miRNAs in human (miRBase version 20) [4]. Most miRNAs are transcribed by RNA polymerase II as primary transcripts (pri-miRNAs), usually several kilobases long, which fold into hairpin structures containing imperfectly base-paired stem-loop structures [5]. RNase III endonuclease Drosha then cleaves primary miRNAs (pri-miRNAs) into $\sim 70 \mathrm{nt}$ long precursor miRNAs (pre-miRNAs), which are later transported to cytoplasm by RanGTP-dependent dsRNAbinding protein exportin-5 (XPO5) [6]. In cytoplasm, RNase III endonuclease Dicer cleaves pre-miRNAs into mature 
miRNAs which are loaded to RNA-induced silencing complexes. Along with Argonaute (Ago) proteins (mainly Ago1 and Ago2 in mammals) of the complex, miRNAs downregulate gene expression by binding to target mRNAs. Although miRNA binding sites have also been found in 5'-UTR [7] and coding sequence [8] of mRNAs, they preferentially interact with seed-matching sequences in the 3'-UTR of mRNA. One miRNA can downregulate multiple genes due to the short sequence required for mRNA recognition, which is known as the "seed region" spanning between the 2 nd and the 7th (or 8 th) nucleotide of mature miRNAs. Taking both direct and indirect regulations together, it is not rare that a single miRNA can regulate the expression of tens or hundreds of genes.

Considering the enormous regulatory potential of miRNAs, it is not surprising that they play crucial roles in cancer development, progression, metastasis and drug resistance. Out of around 2,600 identified human miRNAs, almost $50 \%$ are located at fragile sites on chromosomes known for having common alterations (i.e., amplification, deletion, and rearrangements) in cancer [9]. Roles of miRNAs in cellular processes like cell cycle progression, proliferation, metabolism, apoptosis, and stress resistance [10] also cannot be overlooked as more than $60 \%$ of human protein coding genes are predicted to be under selective pressure to be regulated by miRNAs [11]. Along with these facts, altered miRNA profiles (up/down regulated) in different cancer types suggest that these tiny molecules may have a role in cancer (therefore, the name oncomirs), and they can be classified either as tumor suppressor or oncogenic depending upon the tissue in which they are expressed and the targets they regulate [12]. Among oncogenic miRNAs, miR-17 -92, miR-21, miR-155, miR221, and miR-222 are well-studied, and their overexpression has been found in various human cancers. During lymphomagenesis, elevated miR-17 92 (a cluster of 6 miRNAs) expression has been reported which allows continuous activation of oncogenic PI3K and NF-kB signaling by suppressing negative regulators of these pathways [13]. Another oncogenic miRNA, miR-21, is upregulated in lung, prostate, breast, and pancreatic cancers compared to normal tissues [14]. miR-21 has been shown to be involved in the onset of inflammatory bowel disease (IBD)-associated colorectal carcinoma [15]. Similarly, in breast cancer, knockdown of miR-21 inhibited tumor growth and enhanced apoptosis by downregulating anti-apoptotic protein Bcl-2 [16]. Importantly, a transgenic mouse model has demonstrated that miR-21 overexpression has a causal role in tumor initiation and progression of pre-B malignant lymphoid-like tumors [17]. miR-155 is overexpressed in pancreatic cancer where it promotes tumor development by repressing the expression of tumor suppressor Tp53INP1, and oligonucleotide-mediated inhibition of miR-155 restored Tp53INP1 levels along with significant increase in apoptotic cell death [18]. Among tumor suppressor miRNAs, the most studied ones are the let-7 family miRNAs, whose expression is downregulated in different cancer types. In addition to negative regulation of Ras oncogene [19], let-7 family miRNAs target a network of cell cycle-associated genes, including E2F5, CCNA2, and CDK8, hence playing important roles in regulating multiple proliferation pathways and controlling tumor growth [20]. miR-34 is another wellstudied tumor-suppressor miRNA which is directly regulated by p53 and controls p53-mediated cell death. Low miR-34 expression attenuates $\mathrm{p} 53$-mediated apoptosis and contributes to tumor development [21]. Other tumor suppressor miRNAs include miR-15, miR-16, miR-29, miR-124a, miR-127, miR143, miR-145, and miR-181 [22]. Taken together, their function as negative regulators of multiple targets in biological networks and their common dysregulation in cancer make miRNAs attractive targets for cancer therapy.

This review focuses on the role of miRNAs in drug resistance, metastasis, stemness, and the interplay of these factors in tumor progression, and describes the recent developments in studying miRNA-protein interaction networks and targeting approaches in cancer. We first review recent literature with respect to the role of miRNAs in conferring resistance or sensitizing tumor cells to chemo- or targeted-therapy agents. Next, we focus on how miRNAs regulate different steps of metastasis and stemness properties of cancer cells. We then give an overview of recent studies which link miRNAs with epithelial-mesenchymal transition (EMT), stemness, and drug resistance. Finally, we focus on network-level studies to elucidate the role of miRNAs in all these cancer-relevant processes and discuss the recent developments with respect to targeting miRNAs efficiently and advance in delivery of these molecules to target tumor cells.

\section{The role of miRNAs in drug resistance}

Chemotherapy is the treatment of cancer with single or multiple cytotoxic drugs which mostly work by inhibiting the proliferation of actively dividing cells. These drugs include alkylating agents, platinum agents, nitrogen mustards, antimetabolites, anthracyclins, alkaloids, taxanes, etc. [23]. Nonspecific cell targeting and late stage side effects of chemotherapy has led the way towards designing targeted therapy agents which specifically target the cancer cells by blocking the function of dysregulated proteins in oncogenic pathways. Small molecule inhibitors (mostly tyrosine kinase inhibitors, TKIs) and monoclonal antibodies are the two major classes of targeted therapy agents [24]. While monoclonal antibodies target cell-surface proteins, small molecule inhibitors can inhibit their targets inside the cell in a reversible or irreversible manner. Recently, antibody-conjugated chemotherapy agents combining targeted therapy with chemotherapy on one molecule (e.g., trastuzumab-emtansine or T-DM1 [25]) have also been developed as next-generation treatment agents and 
approved for clinical use. Unfortunately, resistance to both chemotherapy and targeted therapy agents has been found inevitable and reoccurring in cancer treatment. Resistance can be divided into two groups: intrinsic (de novo) or acquired. Intrinsic resistance is an in-built, pre-existing phenotype, whereas the acquired resistance develops due to repeated use of the same drug. They both result in non-responsive treatment [26]. Possible mechanisms include decreased drug uptake, activation of detoxifying systems and DNA repair mechanisms, increased drug efflux, dodging drug-induced apoptosis, inducing secondary mutations, and activation of alternative survival pathways [27-29].

miRNAs have been associated with drug resistance to both chemo- and targeted-therapies (Table 1). Inhibition of miR-21 has been reported to increase gemcitabine sensitivity in cholangiocarcinoma and to inhibit the growth of topotecan-treated MCF7 cells [30]. Let-7e was found to be downregulated in cisplatin-resistant ovarian cancer cells due to the hypermethylation of its adjacent $\mathrm{CpG}$ islands compared with parental cells, and its re-expression has been shown to increase cisplatin sensitivity by reducing the levels of EZH2 and Cyclin D1 [31]. In medulloblastoma, miR-34a has been demonstrated to sensitize cancer cells to mitomycin $\mathrm{C}$ and cisplatin by directly targeting the oncogenic gene MAGE-A, and to induce apoptotic cell death by modulating tumor suppressor $\mathrm{p} 53$ levels in a positive feedback loop [32]. In another study, miR-137 has been shown to target constitutive androstane receptor (CAR), which is an important regulator of multi-drug resistance (MDR), and its overexpression sensitized neuroblastoma, hepatocellular carcinoma (HCC), and colon cancer cells to doxorubicin [33]. Notably, silencing of both Dicer and TRPB2, two key components of miRNA biosynthesis, in cisplatin-resistant adenocarcinoma cells led to reversal of cisplatin resistance without affecting the cell viability in the

Table 1 List of chemo- or targeted therapy agents which modulate the expression of given miRNAs associated with resistance to these drugs

\begin{tabular}{|c|c|c|c|c|}
\hline Drugs & $\begin{array}{l}\text { Downregulated } \\
\text { miRNAs }\end{array}$ & Upregulated miRNAs & Cancer type & References \\
\hline 5-Fluorouracil & & let-7g, miR-181b & Colon & [162] \\
\hline \multirow[t]{2}{*}{ Camptothecin } & & miR-506 & Colon & [163] \\
\hline & miR-203 & & Chronic myeloid leukemia & [37] \\
\hline Cetuximab & let- $7 b$, let-7e & $\operatorname{miR}-17 *$ & Colon & [164] \\
\hline \multirow[t]{3}{*}{ Cisplatin } & let-7e & & Ovarian & {$[31]$} \\
\hline & & miR-302 & Head and neck squamous CSCs & [87] \\
\hline & & miR-203 & Breast & [165] \\
\hline \multirow[t]{2}{*}{ Doxorubicin } & $\operatorname{miR}-451$ & & Breast & [166] \\
\hline & miR-137 & & Hepatocellular, colon & {$[33]$} \\
\hline Erlotinib & $\operatorname{miR}-7$ & & Head and neck & [167] \\
\hline Fulvestrant & & miR-221/222 & Breast & {$[42]$} \\
\hline Gefitinib & miR-146a & & Non-small cell lung & [168] \\
\hline \multirow[t]{2}{*}{ Gemcitabine } & & miR-21 & Cholangiocarcinoma & {$[30]$} \\
\hline & miR-200 & miR-21 & Pancreatic CSCs & [89] \\
\hline Irinotecan & $\operatorname{miR}-451$ & & Colon CSCs & {$[88]$} \\
\hline Letrozole & & $\operatorname{miR}-128 \mathrm{a}$ & Breast & [169] \\
\hline Mitomycin C & miR-34a & & Medulloblastoma & {$[32]$} \\
\hline Mitoxantrone & & miR-328 & Breast & {$[170]$} \\
\hline Paclitaxel & let-7e & $\begin{array}{l}\text { miR-130a, miR-30c, } \\
\text { miR-335, miR-125b }\end{array}$ & Ovarian & {$[171]$} \\
\hline \multirow[t]{2}{*}{ Sunitinib } & & $\operatorname{miR}-21$ & Glioblastoma & {$[172]$} \\
\hline & miR-141 & & Renal cell & [173] \\
\hline \multirow[t]{2}{*}{ Tamoxifen } & & miR-221/222 & Breast & {$[40,41]$} \\
\hline & $\operatorname{miR}-375$ & & Breast & [43] \\
\hline Temozolomide & miR-145 & & Glioblastoma & [158] \\
\hline Topotecan & & miR-21 & Breast & {$[30]$} \\
\hline \multirow[t]{2}{*}{ Trastuzumab } & & miR-21 & Breast & {$[38]$} \\
\hline & & miR-210 & Breast & {$[39]$} \\
\hline Vinblastin & miR-27a, miR-451 & & Ovarian & {$[174]$} \\
\hline
\end{tabular}


absence of the drug, highlighting the general effect of the miRNA biogenesis pathway in chemotherapy resistance [34].

Similarly, miRNAs have also been shown to regulate resistance to targeted therapies. TKI imatinib is one of the iconic examples of targeted therapy agents which successfully inhibits the fusion gene BCR-ABL in patients with chronic myelogenous leukemia (CML) [35]. miR-138, a tumor suppressor that is downregulated in thyroid cancer and head and neck squamous cell carcinoma (HNSCC), was found to be upregulated upon treatment of CML cells with imatinib which resulted in an increase in imatinib-induced apoptosis and increased sensitivity to the drug [36]. This effect was mediated mainly by targeting the open reading frame (ORF) of ABL fragment in the BCR-ABL fusion protein. Similarly, Li et al. have shown that miR-203 targets the 3'-UTR of ABL and leads to sensitization of cells to imatinib in CML cells [37]. Trastuzumab is another iconic drug targeting overexpressed ErbB2 on the cell surface and has been approved by Food and Drug Administration (FDA) for breast cancer since 1998. However, development of resistance is a major problem and involvement of miRNAs in trastuzumab resistance is recently realized. Gong et al. observed overexpression of a well-known oncogenic miRNA, miR-21, in acquired trastuzumab resistant breast cancer cell lines, which confers trastuzumab resistance in both in vitro and in vivo settings. Furthermore, they demonstrated that upregulation of miR-21 is associated with poor response of patients receiving preoperative trastuzumab therapy [38]. Another study reveals that the level of miR-210 was higher in the plasma of breast cancer patients with residual disease when compared to the patients with pathological complete response under neoadjuvant trastuzumab-based chemotherapy [39]. Tamoxifen, an estrogen receptor (ER) antagonist, has been used for treating ER-positive breast cancer for decades. While it has an impressive clinical record, de novo or acquired resistance is very common. Two independent studies have associated miR-221/222 with resistance to tamoxifen, by establishing miR-221/222 downregulating the expression of ER alpha [40] and p27/Kip1 [41]. Furthermore, it has been shown that miR-221/222 also confers resistance to fulvestrant, a selective ER downregulator (SERD), by modulating both $\mathrm{Wnt} / \beta$ catenin and TGF- $\beta$ pathways [42]. We have recently demonstrated that miR-375 is downregulated in tamoxifen resistant MCF-7 cells compared with parental ones and re-expression of miR-375 sensitized resistant cells to tamoxifen partially by downregulating the oncogene metadherin (MTDH) [43]. Altogether, these reports clearly indicate the involvement of miRNAs in resistance to both chemotherapy and targeted therapy, and these miRNAs may be therapeutically modulated to sensitize tumor cells again to the drugs.

\section{Multiple level regulation of metastasis by miRNAs}

The majority of cancer deaths are not caused by primary tumors, but rather by the dissemination of the disease, i.e., the development of distant metastases. Metastasis is accomplished in two major steps: dissemination and colonization. Dissemination phase includes local invasion, intravasation into the systemic circulation, survival in the circulatory system and extravasation. Colonization phase includes the adaptation of these cells to a foreign microenvironment where the microscopic cells turn into macroscopic tumors [44]. The whole process is outcome of the interplay between genetic and epigenetic modifications in tumor as well as in the tumor microenvironment. miRNAs have recently been discovered as the key molecules regulating almost all the steps of metastasis by targeting key genes. They can either promote metastasis (in the case of, e.g., miR373, miR-151, miR-520, miR-143, or miR-10b) or suppress the process (in the case of, e.g., miR-9, miR-139, miR-335, miR-125, or miR-206) [45, 46].

As an initial step of the metastatic cascade, cancer cells need to break away from the primary tumor, migrate and invade the surrounding tissue. In cancers of epithelial origin, increasing evidence has amounted suggesting a developmental program known as EMT which is indispensable for cancer cells to acquire properties favoring migration and invasion. During EMT, cells lose epithelial characteristics, such as apical-basal polarity and tight cell-cell adhesion, and adopt a mesenchymal phenotype characterized by extension formation, reorganization of actin cytoskeleton and decreased cellcell adhesion, all of which contribute to the increased motility and invasiveness (reviewed in [47]). EMT is driven by a group of transcription factors that act as transcriptional repressors of E-Cadherin, including Snail (SNAI1), Slug, ZEB (ZEB1 and ZEB2/SIP1), and basic helix-loop-helix families (Twist1 and E47). miRNAs substantially contribute to EMT by regulating expression of several transcription factors and actin cytoskeleton modulators (Table 2). A subset of these miRNAs, the miR-200 family, is downregulated in metastases compared to primary tumors $[48,49]$ and plays a central role in the inhibition of metastasis by forming a double-negative feedback loop with ZEB1 and ZEB2, both of which are the transcriptional repressors of cell-cell contact protein E-Cadherin [50, 51]. Similarly, p53 activation leads to downregulation of EMTinducing transcription factor Snail in different cancer types by recruiting miR-34a/b/c which directly targets the $3^{\prime}$-UTR of the Snail gene. The promoters of these miRNA genes are bound by Snail and ZEB1 to inhibit the expression of miR$34 \mathrm{a} / \mathrm{b} / \mathrm{c}$, thus completing a double-negative feedback loop [52, 53]. In addition to targeting essential transcription factors regulating EMT, we and others have shown that the miR200 family also target actin regulatory proteins such as FHOD1, PPM1F and moesin to inhibit EMT [54, 55]. 
Table 2 List of miRNAs and their targets involved in regulation of different stages of metastasis in different cancer types

\begin{tabular}{|c|c|c|c|c|c|}
\hline miRNA & Target (Direct/Indirect ${ }^{\mathrm{a}}$ ) & Suppress/promote & Cancer type & Metastasis stage & References \\
\hline miR-200c & BMI1 & Suppress & Head and neck & EMT & [91] \\
\hline miR-34 & Snail & Suppress & Breast, lung, colon & EMT & {$[52,53,96]$} \\
\hline miR-29b & $\begin{array}{l}\text { ANGPTL4, LOX, MMP2, } \\
\text { MMP9, VEGFA, PDGF }\end{array}$ & Suppress & Prostate/hepatocellular & EMT & {$[175,176]$} \\
\hline miR-30a & Snail & Suppress & Non-small cell lung & EMT & {$[177]$} \\
\hline miR-200 family & TGF $\beta 2$, ZEB1, ZEB2 & Suppress & $\begin{array}{l}\text { Pancreatic, colorectal, } \\
\text { breast, lung }\end{array}$ & EMT, invasion & {$[48,50,51]$} \\
\hline miR-22 & TET family members & Promote & Breast & EMT, invasion & {$[95]$} \\
\hline miR-200b & Moesin & Suppress & Breast & EMT, invasion & {$[55]$} \\
\hline miR-200c & FHOD1, PPM1F & Suppress & Breast & EMT, invasion, migration & {$[54]$} \\
\hline $\operatorname{miR}-7$ & KLF4 & Suppress & Breast & Invasion & [93] \\
\hline $\operatorname{miR}-135 b$ & LATS2, $\beta$-TrCP, NDR2, LZTS1 & Promote & Non-small cell lung & Invasion, migration & [178] \\
\hline miR-10b & HOXD10 & Promote & Breast & Invasion, migration & [179] \\
\hline miR-34a & CD44 & Suppress & Prostate CSCs & Invasion, migration & {$[94]$} \\
\hline miR-21 & Pdcd4 & Promote & Lung & Invasion, intravasation & {$[56]$} \\
\hline $\begin{array}{l}\text { miR-520/373 } \\
\text { family }\end{array}$ & $\begin{array}{l}\text { TGFBR2 (NF-kB and TGF- } \beta \\
\text { pathways) }\end{array}$ & Suppress & Breast & Invasion, intravasation & {$[60]$} \\
\hline miR-493 & IGF1R & Suppress & Colon & Extravasation & {$[58]$} \\
\hline $\operatorname{miR}-148 b$ & $\begin{array}{l}\text { ITGA5, ROCK1, PIK3CA/p110 } \alpha \text {, } \\
\text { NRAS, CSF1 }\end{array}$ & Suppress & Breast & $\begin{array}{l}\text { Invasion, extravasation, } \\
\text { survival to anoikis }\end{array}$ & {$[59]$} \\
\hline miR-214 & TFAP2 & Promote & Melanoma & Extravasation & {$[180]$} \\
\hline $\operatorname{miR}-31$ & Integrin $\alpha 5$, Radixin, RhoA & Suppress & Breast & Extravasation, colonization & {$[57]$} \\
\hline miR-200 family & $\operatorname{Sec} 23 \mathrm{a}$ & Promote & Breast & Colonization & {$[62]$} \\
\hline miR-612 & Akt2 & Suppress & Hepatocellular & Colonization & {$[46]$} \\
\hline
\end{tabular}

${ }^{\text {a }}$ Denotes that indirect targets in the given study are shown in italics

Besides regulating EMT to drive cancer cells more motile and invasive, miRNAs also regulate cell intravasation to the circulatory system as well as the post-intravasation steps including extravasation and initial survival at the distant tissue. Asangani et al. have shown that inhibition of miR-21 in colorectal cancer cells reduced intravasation and lung metastasis in a chicken embryo metastasis assay by upregulating the expression of its target Pdcd4, a tumor suppressor gene [56]. miR-31 has been demonstrated to regulate several postintravasation steps including intraluminal viability, extravasation, and survival at distal tissue in addition to the invasion and metastatic colonization steps by simultaneous targeting of three key genes: integrin $\alpha 5$ (ITGA5), radixin (RDX), and RhoA (RHOA) [57]. Recently, Okamoto et al. identified miR493 as an inhibitor of the settlement of colon cancer cells to the liver parenchyma in a functional miRNA screen. They demonstrated that miR-493 directly targets the receptor tyrosine kinase IGF-1R and this in turn leads to the apoptosis of metastasized cells [58]. Very recently, it is reported that miR$148 \mathrm{~b}$ regulates both extravasation and survival of breast cancer cells in circulation in both in vitro (apoptosis assay) and in vivo (tail-vein injection for extravasation to the lungs) experiments. Data indicated that miR-148b reduced both extravasation and survival by regulating metastatic dissemination in several steps [59]. Recently, we have shown that miR-520/373 family inhibits both in vitro cell invasion and in vivo intravasation of highly invasive ER (-) breast cancer cells. Decreased expression of miR-520c was found to be correlated with the lymph node metastasis of ER (-) breast cancer patients [60].

The final step of metastasis is successful colonization of tumor cells at a distal organ site. Different tumors have different preferences for the site of metastasis. This observation forms the basis of century-long seed-and-soil hypothesis where "seed" represents the "cancer cells" and the "soil" stands for the "tumor microenvironment" [44]. Consistent with this hypothesis, breast cancer cells metastasize frequently in bone, lungs, liver, and brain, while pancreatic cancers preferentially metastasizes to liver and lungs (reviewed in [61]). Few studies have focused on the roles of miRNAs in the colonization step. Korpal et al. demonstrated that miR-200 promotes the colonization of breast cancer cells by directly targeting the Sec23a gene which is involved in the secretion of metastasis-suppressive proteins. This study is also a good example of dichotomous function of miRNAs in the initiation (i.e., inhibiting EMT) and final colonization (i.e., promoting colonization) steps of metastasis [62]. Recently, miR-612 is suggested to suppress the colonization of HCC cells to the 
lungs [46]. Finally, as discussed above, miR-31 regulates colonization by targeting ITGA5, RDX and RHOA protein network.

Several recent studies demonstrated that miRNAs can sensitize cells to given drugs by modulating the EMT step of metastasis, implying an intriguing link between metastasis and drug resistance (Fig. 1, Supplementary Table 1). miR-200c, a downregulated miRNA in melanocytes, targets BMI-1 when overexpressed, leading to increased E-cadherin levels and thereby inhibiting metastatic potential of cancer cells. In the same study, it was also shown that overexpression of miR-200 inhibits cell proliferation and resistance to cisplatin, PLX4720 and U0126 [63]. Re-expression of miR-200c in non-small cell lung cancer (NSCLC) inhibited invasion by maintaining epithelial phenotype and improved the sensitivity of cancer cells to cetuximab and cisplatin [64]. Treatment of gemcitabine resistant pancreatic cancer cells with natural agents (DIM and isoflavone) induces miRNAs of both miR-200 and let-7 families, which restore the epithelial state and improve the sensitivity to gemcitabine [65]. As previously discussed, we have recently demonstrated that re-expression of miR-375 in tamoxifen resistant MCF-7 cells sensitized resistant cells to tamoxifen by reversing the mesenchymal phenotype of resistant cells to more epithelial one [43]. miR-23, an oncogenic miRNA, has been shown to be upregulated in lung adenocarcinoma cells driving EMT. Downregulation of this miRNA in
A549 lung cancer cells restored epithelial phenotype along with enhancing sensitivity for gefitinib [66]. miR-216a/217 target PTEN and SMAD7, antagonists of PI3K and TGF- $\beta$ signaling pathways, respectively, and assist in maintaining drug resistance and high metastatic potential in HCC. Inhibiting miR-216/217 or overexpressing their targets rescued EMT and sensitized cancer cells to sorafenib [67]. Altogether, these findings suggest that miRNAs regulate metastasis at multiple steps by modulating different components of the cellular networks and modulation of EMT by miRNAs can sensitize the cells to chemo- or targeted-therapy agents.

\section{miRNA regulation of stemness, EMT, and drug resistance in cancer}

Stemness is the ability of a cell to differentiate into any other cell type (potency) while maintaining an undifferentiated state (self-renewal) [68]. Adult stem cells have been found in almost every tissue type and organ maintaining tissue homeostasis and in regenerating tissues after injury or damage [69, 70]. The connection between stemness and tumor initiation was first shown when a population of leukemic cells expressing surface markers identical to hematopoietic stem cell (HSC) markers (CD34+/CD38-) was found to initiate acute myeloid leukaemia tumors in NOD/SCID mice [71]. Later on,

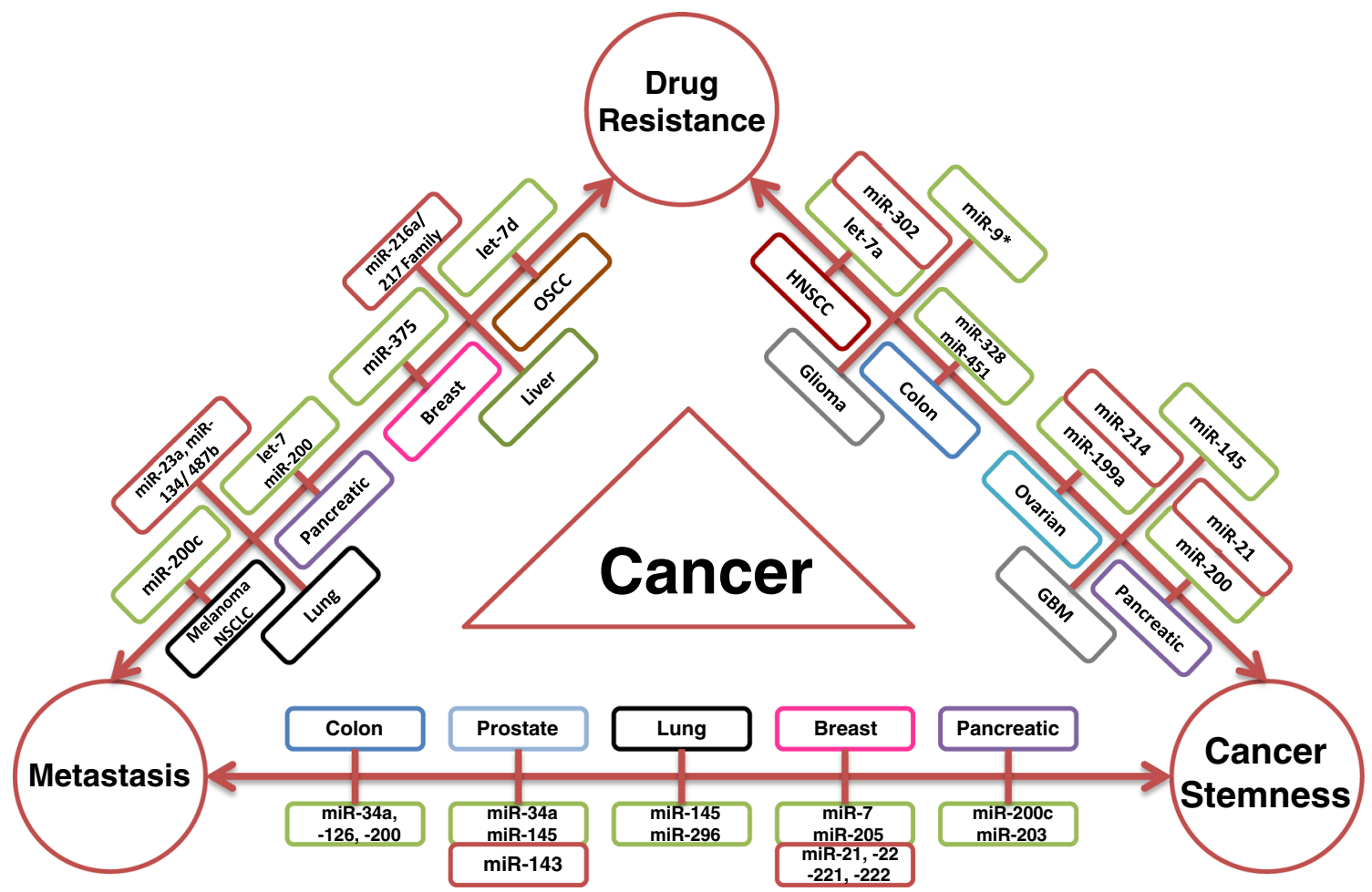

Fig. 1 MicroRNAs play master role in the interplay of drug resistance, metastasis and cancer stemness. A brief outlook of miRNAs reported to co-regulate any two of these mechanisms in a specific cancer type are shown [43, 63-67, 79, 86-89, 92-96, 150-161] where oncogenic (upregulated) miRNAs are marked with red and tumor suppressor (downregulated) miRNAs are marked with green background. OSCC oral squamous cell carcinoma, NSCLC non-small cell lung carcinoma, $H N S C C$ head and neck squamous cell carcinoma, GBM glioblastoma 
cancer stem cells (CSCs), also known as tumor initiating cells (TICs), were identified in a number of solid tumors including breast, brain, colon, prostate and pancreatic cancer [72-76]. Although involving similar pathways (e.g. Wnt, Notch and TGF- $\beta$ signaling), CSCs distinguish themselves from normal stem cells by altered molecular profiles. For example, leukemic stem cells require loss of tumor suppressor PTEN to be distinguished from HSCs [77]. CSCs represent small population in tumor [78], but in addition to maintaining stemness, they also take part in driving tumor growth, metastasis, and drug resistance [79]. Several miRNAs have been shown to regulate stemness of different cancer types. For instance, three miRNA clusters (miR-200c-141, miR-200b-200a-429, and miR-183-96-182) have been found downregulated in both normal and CSCs to overexpress Bmil which plays a role in stem cell renewal [80]. Recently, a comparative expression analysis of CD44+ (a marker for CSCs) and CD44- colorectal cancer cell lines revealed association between miR-203 downregulation and cancer stemness. In CD44+ cells, hyluranon (HA) signaling (HA/CD44 interaction) triggers c-Src kinase mediated nuclear accumulation of Snail, an inhibitor of miR203, resulting in enhanced stemness [81]. Increased expression of miR-21 and miR-302 and decreased levels of let-7a, miR-372, miR-373, and miR-520c-5p were observed in CSCs when compared with cancer cells in a human gastric cancer cell line, suggesting differential expression of miRNAs in CSC and other cancer cell populations [82]. Ji et al. identified higher expression of miR-181 in EpCAM+/AFP+ stem cell population of HCC. Its inhibition resulted in a decrease in this population and tumor initiating capacity of the cells [83]. The oncogenic miR-21 enhanced stem-like properties in colorectal cancer by downregulating transforming growth factor beta receptor-2 (TGF $\beta$ R-2) along with activating the oncogenic Wnt signaling pathway [84].

CSCs are thought to be responsible for the observed resistance to therapy and metastasis. Several miRNAs have been reported to regulate stem cell properties and drug resistance concomitantly (Fig. 1, Supplementary Table 2). CD133 is a well-established CSC marker in brain tumors including glioblastoma (GBM) [85]. Ectopic expression of miR-145 in GBM-CD133+ cells resulted in their differentiation into CD133- non-CSCs and thereby reduced resistance to temozolamide [86]. Due to the Hyaluronan (HA) activation of CD44v3 (an HA receptor) leading to nuclear accumulation of oncogenic transcription factors (Nanog, Oct4, Sox2), CSCs in HNSCC display upregulated miR-302 expression which, in turn, upregulates several survival proteins responsible for clonal formation, self-renewal and cisplatin resistance [87]. miR-451 has been shown to be downregulated in drug resistant colon CSCs, and its restoration antagonized irinotecan resistance and the self-renewal capacity via indirect targeting of COX-2-mediated Wnt-signaling [88]. Decreased miR-200 and increased miR-21 levels have been observed in gemcitabine-resistant pancreatic CSCs, and the treatment of these CSCs with synthetic compound-CDF resulted in tumor inhibition through reversing miR-200 and miR-21 expression, which modulates stemness-related pathways [89]. miR-26a has been demonstrated to be lost in pancreatic CSCs and its re-expression decreased expression of CSC markers (EpCAM and $\mathrm{EZH} 2$ ) in pancreatic cancer. In this respect, it was an interesting observation that pancreatic CSCs treated with metformin showed increased expression of six miRNAs including miR-26a and decreased expression of different CSC markers [90].

Similar to the critical role of miRNAs in the interplay of stemness and drug resistance, miRNAs also co-regulate stemness and metastatic capabilities of the cells, especially by regulating the EMT process (Fig. 1, Supplementary Table 3). It has been shown that the expression of miR-200c was downregulated, while its target Bmil was upregulated in ALDH1+/CD44+ HNSCC cells compared with other cell populations. Notably, overexpression of miR-200c in these CSC populations inhibited CSC-like properties, decreased the expression of EMT-associated ZEB1 and Snail, and inhibited the lung metastasis capability of the cells [91]. Importantly, ZEB1 has been shown to work in a feedback loop with miR200 and also to play a role in repression of stemness inhibiting miRNAs (e.g. miR-203). This way ZEB1 controls both EMTactivation and cancer stemness maintenance [92]. In another study, CSC population (CD24-/CD44+/ESA+) isolated from highly metastatic breast cancer cells were found more capable of metastasis than the non-CSC population. miR-7 was shown to be downregulated in bone and brain metastases derived from these CSCs and its re-expression in breast CSCs suppressed brain metastasis by downregulating KLF4, a stemness related gene [93]. miR-34a has been shown to be downregulated in CD44+ prostate CSCs and its re-expression or knocking down of its direct target CD44 suppressed both tumor growth and metastatic capacity in prostate cancer [94]. Very recently, Song et al. demonstrated that miR-22 promotes EMT and increases stem cell population of mammary tumors, resulting in increased metastasis potential of different transgenic mammary tumor models. Mechanistically, miR-22 exerts its metastatic properties by directly targeting the TET family of methylcytosine dioxygenases, leading to reduced expression of antimetastatic miRNAs, particularly the miR-200 family [95]. Finally, another recent study demonstrated that disruption of Dicer in colorectal cancer cells resulted in decreased expression of key tumor suppressor miRNAs, miR-200 family and miR-34a, which, in turn, led to the enrichment of stemness properties and the induction of EMT with increased liver metastasis of colorectal cells [96]. In conclusion, miRNAs play crucial roles in maintaining cancer stemness, associated-drug resistance and metastasis, and targeting miRNAs regulating the interplay of stemness with metastasis 
and drug resistance might be more effective in preventing metastasis or overcoming resistance to both chemo- and targeted-therapy.

\section{Systems biology approaches to identify miRNA-protein interaction networks regulating drug resistance and metastasis}

Our understanding of miRNAs and their functions in drug resistance, metastasis, and cancer stemness is continuously amounting but still limited. The observation that each miRNA can have many targets and that each gene can be regulated by multiple miRNAs implies that studies designed with "one miRNA vs. one target" concept are likely to be flawed. Therefore, cancer researchers have long embraced the concept of systems biology and combined wet-lab experiments with bioinformatics analysis in order to elucidate how miRNAs operate on the network level by regulating many targets at a time.

The necessity and usefulness of studying miRNA regulation of genes or proteins at network level have been demonstrated by several groups. Pencheva and Tavazoie reported in a recent review that a number of different miRNAs promote or suppress metastasis by forming functional networks with their targets in three fashions: cell-autonomous, cell-nonautonomous, or a mixed of the two [97]. The more than onehundred studies on miRNA-protein networks that were reviewed do not only offer novel insights into their roles in metastasis, but also stimulate and accelerate the discovery of genes and pathways that control various aspects of the biological process. In another study focusing on general principles of systems biology approaches to study miRNAs in cancer, Vera et al. promoted the idea that systems biology and molecular biology approaches must be integrated. To support this idea, they demonstrated the feasibility of using a mathematical tool (ordinary differential equations, ODE) to predict functions of miRNA by modeling and simulation [98]. Another study by Aguda et al. demonstrated the feasibility of using mathematical models to elucidate a miRNA regulated cancer network where a miRNA cluster, miR-17-92, inhibited the expression of MYC and E2F transcription factors which, in turn, induced the expression of miR-17-92 cluster providing a negative feedback loop. In this study, the generated model predicted that miR-17-92 plays an important role in regulating the expression levels of these proteins [99]. Furthermore, a recent study generated a kinetic model using the knowledge on E2F, p73 and miR-205 and proposed that high E2F1, low miR-205 and high ErbB3 levels make the cancer cells resistant to both genotoxic and cytotoxic drugs [100].

To study microRNAs' roles in the context of biological networks experimentally, either forward-engineering or reverseengineering approaches have been used (Fig. 2). Forwardengineering approaches are forward-genetics experiments where one or more miRNAs (or genes) are either inhibited or overexpressed by genomic integration [101], chemical inhibitors or mimics [102], expression constructs [103] or other tools. To identify target genes and study the regulatory effects (amplitude, dynamics, etc.), expression profiles of genes or miRNAs are measured. Omics technologies, such as gene/miRNA microarrays [104], next-generation sequencing [105], protein arrays [106], and mass spectrometry [107], are often used to identify potential targets, since they can cover a large number of genes in an almost unbiased way. The obvious challenge is that except for special cases, it is difficult to dissect direct from indirect effects in such experiments. Therefore, computationally predicted microRNA/gene target pairs are often used to filter large number of potential hits (reviewed in $[108,109])$. Furthermore, downstream experiments are usually required, often in a lowthroughput manner, to validate the findings. For instance, to validate direct miRNA-gene regulations, one possibility is to couple point mutation of miRNA-binding regions in $3^{\prime}$-UTR of target genes with luciferase assays [43] [54]. It is expected that technological development will strongly boost the forward inference approaches. Future experiments may bring more power and insight by becoming more multiplex [110] and by integrating multilayer and heterogeneous data [111]. Increasing throughput and lower costs will allow more data generated to fine-map expression of miRNAs and their targets in different tumor types and disease stages $[112,113]$. New technologies such as next generation sequencing [114] and high-throughput mass spectrometry [115] and other quantification methods [106] are pushing the fronts of forward-engineering approaches.

In contrast to forward-engineering approaches, reverseengineering approaches often deal with expression profiles that were not generated by specific perturbation of genes or miRNAs. A typical example is paired expression profiling of mRNA and miRNA in drug-sensitive and drug-resistant cell lines. In such settings, the primary goal is to recover miRNAgene, gene-gene and though less commonly, miRNA-miRNA regulatory relationships. Various network-inference algorithms such as correlation-based methods [116], Bayesian network methods [117], regression-based methods [118], and modeling-based approaches [119] have been applied to infer the structure of miRNA-protein networks.

Finally, combining forward and reverse engineering approaches allows biologists to construct comprehensive regulatory networks incorporating transcription factors (TFs), target genes, miRNAs, and chemical compounds. Many algorithms and tools that are available to study both global and local properties of networks (reviewed in $[120,121]$ ) have been applied to miRNAprotein interaction networks. For instance, it has been observed that miRNAs and TFs are often involved in network motifs, namely local network structures that are more abundant than a random network model would have predicted, such as feedback loops and feed-forward loops [122, 123]. Applications exploiting these properties are emerging to improve therapeutic regimens 
a

microRNA mimics/inhibitors
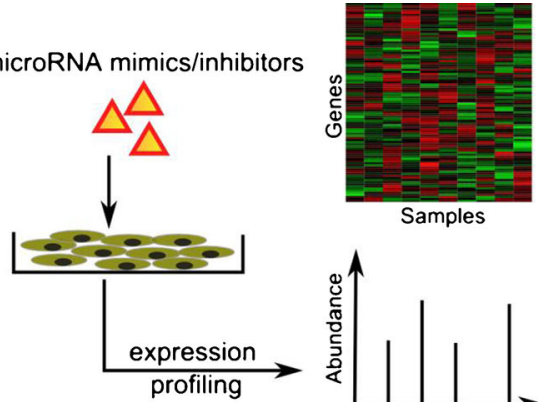

Statistical and bioinformatics

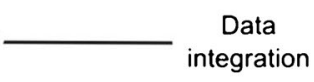

$$
\text { Samples }
$$

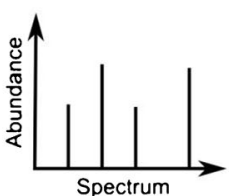

analysis
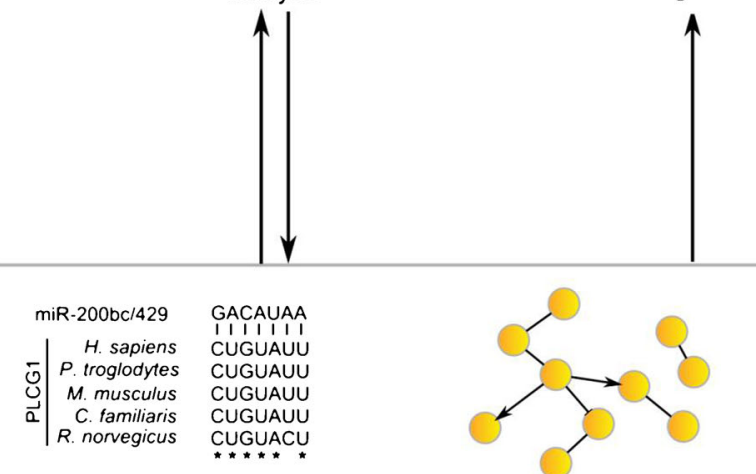

Computationally predicted and Topology of biological networks, such as experimentally verified gene regulatory network, signaling network

b

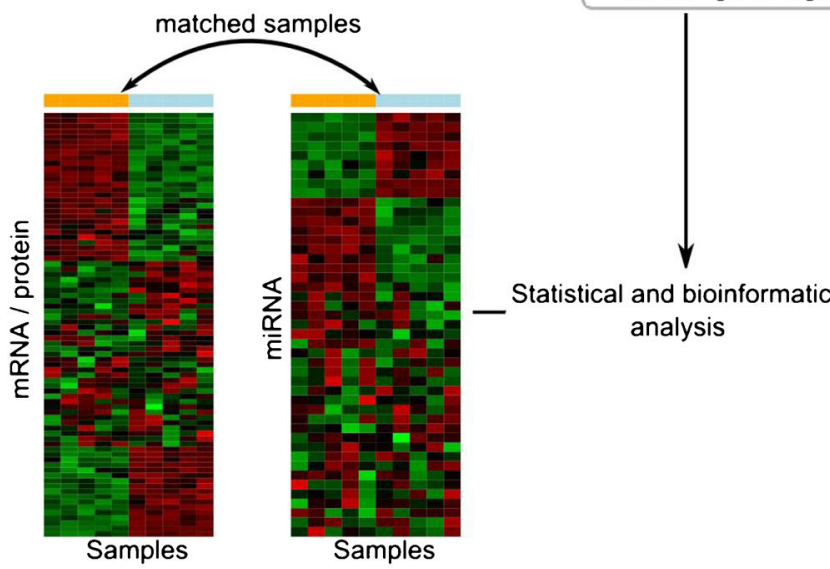

\section{satoss} and protein-protein interaction network

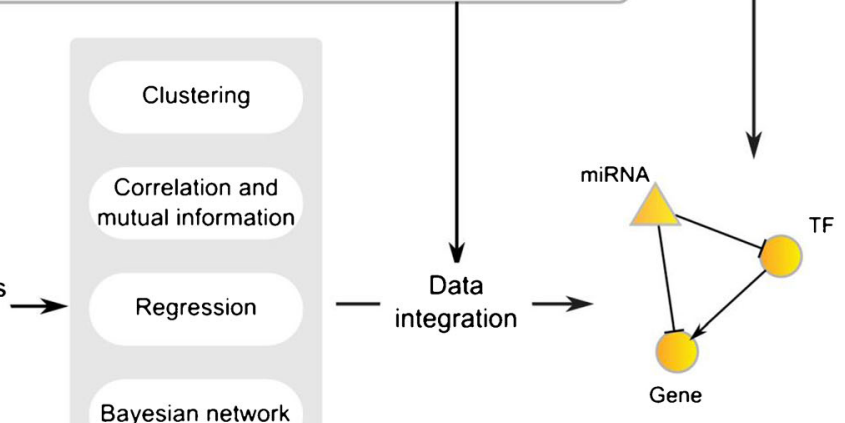

Topology identification experiment validation

Ordinary differential equations and network analysis

Fig. 2 Workflow diagrams of forward-engineering (a) and reverseengineering (b) approaches to identify the "wiring-diagram" of microRNA-protein networks. Forward-engineering methods generally begin with targeted perturbation of microRNA (illustrated here as example) or gene expression. Omics technologies such as mRNA and protein expression profiling are coupled with in silico methods to detect targets or regulators of microRNAs. In contrast, reverse-engineering methods attempt to make inference about the network structure by applying machine

and to enable new therapeutics against cancer. For instance, Zhang et al. reported the blockage of a miR-21/EGFR regulatory feedback loop by combining nimotuzumab (an EGFR targeting antibody) and a miR-21 inhibitor augments anti-EGFR therapy in GBM [124]. In another study, disruption of the MYC-miR26a-EZH2 feed-forward loop with small-molecule compounds was found to suppress lymphoma growth and clonogenicity in aggressive lymphoma cells [125]. Both integrative basic research and translational studies are further called to elucidate miRNA regulatory networks and to transform knowledge in network biology of miRNAs into biomarkers and therapies. Researchers can benefit from evolving technologies, amounting data shared
Network inference algorithms

learning algorithms to paired expression data of microRNA and mRNAs (or proteins). In either case, prior knowledge can be integrated to the analysis pipeline, and often downstream experiments are required to validate the findings. The aim of both types of approaches is to build a comprehensive microRNA-protein network. Its local and global properties provide insights to the network-level mechanism of microRNA regulation, and create opportunity for novel therapeutic interventions against cancer

in public databases such as Pharmaco-miR [126], miR2Disease [127], and OncomiRDB (http://bioinfo.au.tsinghua.edu.cn/ member/jgu/oncomirdb), novel bioinformatics algorithms and new experimental systems such as high-throughput in vivo screening [128].

\section{Promises and challenges in targeting miRNAs in cancer}

Dysregulated miRNA expression and their roles as oncogenes or tumor suppressors by targeting protein networks make miRNAs a promising option to sensitize cancer cells to 
therapy or to prevent metastasis. The notion of modulating miRNAs in cancer comes from the analogy of killing two birds (drug resistance and metastasis) with one stone (miRNA). As we have discussed above, inhibition of oncogenic miRNAs or replacement of downregulated miRNAs by exogenous expression in different experimental models suppressed tumor growth and metastasis, and even sensitized refractory tumors to different chemotherapy or targeted therapy agents.

There are several strategies being evaluated to target miRNAs or use them as targeting agents in cancer, such as (a) inhibition of oncogenic miRNAs by antisense DNA oligonucleotides, antagomirs, locked nucleic acids (LNAs), RNA sponges, or miR-masking; (b) exogenous expression of tumor suppressor miRNAs; and (c) targeting miRNAs by using small molecules (reviewed in [129]). Early experiments in C. elegans demonstrated the ineffectiveness of using unmodified antisense DNA oligonucleotides. However, 2'-Omethyl or 2'-O-methoxyethyl conjugated oligonucleotides significantly improved binding specificity and affinity for RNA [130]. Later on, "antagomirs" with 2'-O-methyl modifications were developed against miR-122, an abundant miRNA in liver. In vivo injection efficiently downregulated miR-122 expression in mouse liver after $24 \mathrm{~h}$ [131]. This method is specific, efficient, and long-lasting, and has led to more antogomirs that are being tested. Another approach to inhibit miRNAs uses LNAs which are oligonucleotides with ribose ring "locked" by methylene bridge between 2'-O and $4^{\prime}-\mathrm{C}$ atoms. It improves target specificity and affinity towards complementary miRNA sequences. Recently, LNA-mediated downregulation of miR-155 has been shown to decrease tumor growth in chronic lymphocytic leukemia (CLL) [132]. Complementarily, expression of tumor suppressor miRNAs can be restored by direct or vector-based transfection of miRNA mimics. For example, intranasal administration of let-7 has been shown to reduce the tumor formation in lungs of animals expressing G12D-mutated K-Ras oncogene [133]. Similarly, re-expression of miR-29, a miRNA which sensitizes HCC cells to doxorubicin, attenuated the ability of HCC cells to form tumors in mice [134]. Furthermore, systemic (intravenous) delivery of miR-141 or miR-219 inhibits osteolytic bone metastasis in vivo [135]. Last but not least, small molecule inhibitors are being searched for to target miRNAs. A luciferase-based screening with a library of more than 1,000 compounds, for instance identified azobenzene as a potent inhibitor of oncogenic miR-21 expression in HeLa cells [136].

In addition to the development of diverse strategies to target or replace miRNAs, there have been a number of studies aiming to improve the delivery of miRNAs in an efficient and specific manner to target tumor tissues. Initially, vector-based delivery approaches including both adenoviral- and lentiviralbased delivery approaches were proposed to replace the tumor suppressor miRNAs such as, miR-26a [137] and let-7 g [138]. However, they are associated with increased toxicity and induction of immune response, which limit the translation into clinics [139]. As an alternative approach, non-viral delivery approaches e.g. lipid-based nanoparticles containing miRNAs have been developed. Piao et al. demonstrated that lipid-based delivery of miR-107 precursors led to efficient reduction of multiple targets' expression and tumor growth in HNSCC [140]. Furthermore, several other nanoparticle-based miRNA delivery approaches have been reported. For example, Babar et al. reported that PLGA nanoparticles conjugated to a cellpenetrating peptide efficiently delivered the anti-miR-155 into tumor cells and inhibited the growth of pre-B-cell tumors in vivo [141]. In addition to nanoparticles for miRNA delivery, very recently, Ohno et al. demonstrated that EGF-like peptide containing exosomes delivered let-7a to EGFRoverexpressing breast tumors in vivo [142]. Compared with vector-based delivery methods, these synthetic delivery systems are more favorable due to simplicity, allowing more control over the size of particles and the distribution of molecules, while eliciting less immunogenicity, However, currently, these synthetic systems have relatively low efficiency (reviewed in [139]), and it lacks long-time studies with regard to their toxicity. Overall, specific inhibition or replacement of miRNAs and efficient delivery to target sites may hold the promise to sensitize cancer cells to therapy and to prevent metastasis; however, much work has yet to be done to prove their efficacy, safety and clinical applicability.

\section{Conclusion and perspectives}

We have reviewed here the role of miRNAs in drug resistance and metastasis, both of which are the major causes of cancerrelated deaths, and their interplay with cancer stemness. As miRNAs can have a huge impact on the gene expression at the global scale and they are dysregulated in cancer, targeting or replacing miRNAs have great promise for sensitizing cancer cells to therapy agents and for preventing the metastasis. However, before translation of pre-clinical findings into clinics, there need to be significant improvements in several aspects of studying the miRNAs. First, clinically-relevant models and scenarios could be prioritized when studying the role of miRNAs in drug resistance. Most of the studies examining the sensitizer role of miRNAs have been using two dimensional cell culture systems. There established cancer cell lines are continuously cultured in the presence of drug and resistance develops after several months. Such models miss the contribution of tumor microenvironment and oversimplify the therapy regimens used in the clinics. For this purpose, transgenic mouse models or syngeneic tumor transplantation models with intact tumor microenvironment [143] can be used to develop drug resistant animal models. In these 
models miRNAs can be modulated stably and/or inducibly, and the sensitizer effects of miRNAs can be studied. Alternatively, patient-derived xenografts with known therapy history [144] can be used to deliver miRNAs into tissues and to study whether miRNAs can sensitize refractory tumors to the therapy. Secondly, although the role of miRNAs has been relatively well-studied in the initial phase of metastasis, particularly the EMT process [145], how different tumor microenvironment orchestrates the organ-specific metastasis by secreting different miRNAs and whether these miRNAs are really effective in blocking the colonization of cancer cells are still under-studied. Another area where studying the role of miRNAs is limited is cancer stemness which has been hampered by the low number of stem-like cells in heterogeneous tumor population [146]. This may be circumvented by newer technologies such as high-content screening and single-cell sequencing.

Systems biology approaches to integrate miRNAs into gene or protein networks have been developed and being utilized in recent studies $[110,125,147]$. In order to predict the outcome of miRNA modulation in a cell system, models integrating miRNAs into gene or protein networks have to be developed and loss-of-function or gain-of-function simulations should be performed similar to the ones done for protein-coding genes. These models will help understand the mechanism of miRNA regulation at the global scale, and eventually predict efficacy and potential side effects of modulation of miRNAs. Furthermore, more research on the tumor tissue-specific delivery methods for targeting tumors with miRNAs using specific tumor markers on the carriers [142] are needed to reduce the side-effects of treatments. Although we did not focus on the biomarker aspect in this review, miRNAs have a good potential to predict therapy response and outcome due to their stability and ubiquitous presence in body fluids $[148,149]$. There are currently more than dozens of clinical trials using miRNAs or proteins in miRNA biogenesis as biomarkers of tumor progression, metastasis and response to chemotherapy or targeted therapy agents (www. clinicaltrials.gov). More research with larger cohorts and comprehensive designs should be carried out to establish miRNAs as clinically useable biomarkers.

In conclusion, considering the complexities intrinsic to cancer genome, miRNA regulation, and many aspects of fight against cancer - especially the ones we discuss in this review, drug resistance, metastasis, and stemness - we believe that the research community urgently needs better understanding of miRNA-protein interaction networks. We therefore propose that multi-disciplinary systems approaches integrating genomics, genetics, proteomics, and bioinformatics may hold the key.

Acknowledgments We thank Gülce Itır Perçin, Merve Bal, Mustafa Can Kiren and Ezgi Bağırsakçıŏlu for helping us prepare the figures and tables. We thank Dr. Martin Ebeling for insights and discussions on network-based analysis. We apologize to the many authors whose work could not be cited directly because of space limitations. This work was supported by EMBO Installation Grant (ÖŞ), Bilkent University start-up funds (ÖȘ) and the scholarship from Higher Education Commission of Pakistan (UR).

\section{References}

1. He L, Hannon GJ (2004) MicroRNAs: small RNAs with a big role in gene regulation. Nat Rev Genet 5:522-531

2. Singh SK, Pal Bhadra M, Girschick HJ, Bhadra U (2008) MicroRNAs-micro in size but macro in function. FEBS J 275: 4929-4944

3. Inui M, Martello G, Piccolo S (2010) MicroRNA control of signal transduction. Nat Rev Mol Cell Biol 11:252-263

4. Kozomara A, Griffiths-Jones S (2011) miRBase: integrating microRNA annotation and deep-sequencing data. Nucleic Acids Res 39:D152-D157

5. Borchert GM, Lanier W, Davidson BL (2006) RNA polymerase III transcribes human microRNAs. Nat Struct Mol Biol 13:1097-1101

6. Bohnsack MT, Czaplinski K, Gorlich D (2004) Exportin 5 is a RanGTP-dependent dsRNA-binding protein that mediates nuclear export of pre-miRNAs. RNA 10:185-191

7. Orom UA, Nielsen FC, Lund AH (2008) MicroRNA-10a binds the $5^{\prime}$ UTR of ribosomal protein mRNAs and enhances their translation. Mol Cell 30:460-471

8. Forman JJ, Legesse-Miller A, Coller HA (2008) A search for conserved sequences in coding regions reveals that the let-7 microRNA targets Dicer within its coding sequence. Proc Natl Acad Sci U S A 105:14879-14884

9. Calin GA, Sevignani C, Dumitru CD, Hyslop T, Noch E, Yendamuri S, Shimizu M, Rattan S, Bullrich F, Negrini M et al (2004) Human microRNA genes are frequently located at fragile sites and genomic regions involved in cancers. Proc Natl Acad Sci U S A 101:2999-3004

10. Ambros V (2001) microRNAs: tiny regulators with great potential. Cell 107:823-826

11. Friedman RC, Farh KK, Burge CB, Bartel DP (2009) Most mammalian mRNAs are conserved targets of microRNAs. Genome Res 19:92-105

12. Zhang B, Pan X, Cobb GP, Anderson TA (2007) microRNAs as oncogenes and tumor suppressors. Dev Biol 302:1-12

13. Jin HY, Oda H, Lai M, Skalsky RL, Bethel K, Shepherd J, Kang SG, Liu WH, Sabouri-Ghomi M, Cullen BR et al (2013) MicroRNA-17 92 plays a causative role in lymphomagenesis by coordinating multiple oncogenic pathways. EMBO J 32:2377-2391

14. D'Amato NC, Howe EN, Richer JK (2013) MicroRNA regulation of epithelial plasticity in cancer. Cancer Lett 341:46-55

15. Ludwig K, Fassan M, Mescoli C, Pizzi M, Balistreri M, Albertoni L, Pucciarelli S, Scarpa M, Sturniolo GC, Angriman I et al (2013) PDCD4/miR-21 dysregulation in inflammatory bowel diseaseassociated carcinogenesis. Virchows Arch 462:57-63

16. Si ML, Zhu S, Wu H, Lu Z, Wu F, Mo YY (2007) miR-21-mediated tumor growth. Oncogene 26:2799-2803

17. Medina PP, Nolde M, Slack FJ (2010) OncomiR addiction in an in vivo model of microRNA-21-induced pre-B-cell lymphoma. Nature 467:86-90

18. Gironella M, Seux M, Xie MJ, Cano C, Tomasini R, Gommeaux J, Garcia S, Nowak J, Yeung ML, Jeang KT et al (2007) Tumor protein 53 -induced nuclear protein 1 expression is repressed by miR-155, and its restoration inhibits pancreatic tumor development. Proc Natl Acad Sci U S A 104:16170-16175 
19. Johnson SM, Grosshans H, Shingara J, Byrom M, Jarvis R, Cheng A, Labourier E, Reinert KL, Brown D, Slack FJ (2005) RAS is regulated by the let-7 microRNA family. Cell 120:635-647

20. Johnson CD, Esquela-Kerscher A, Stefani G, Byrom M, Kelnar K, Ovcharenko D, Wilson M, Wang X, Shelton J, Shingara J et al (2007) The let-7 microRNA represses cell proliferation pathways in human cells. Cancer Res 67:7713-7722

21. Raver-Shapira N, Marciano E, Meiri E, Spector Y, Rosenfeld N, Moskovits N, Bentwich Z, Oren M (2007) Transcriptional activation of miR-34a contributes to p53-mediated apoptosis. Mol Cell 26:731-743

22. Kasinski AL, Slack FJ (2011) Epigenetics and genetics. MicroRNAs en route to the clinic: progress in validating and targeting microRNAs for cancer therapy. Nat Rev Cancer 11:849864

23. Malhotra V, Perry MC (2003) Classical chemotherapy: mechanisms, toxicities and the therapeutic window. Cancer Biol Ther 2: S2-S4

24. Gerber DE (2008) Targeted therapies: a new generation of cancer treatments. Am Fam Physician 77:311-319

25. Burris HA 3rd, Rugo HS, Vukelja SJ, Vogel CL, Borson RA, Limentani S, Tan-Chiu E, Krop IE, Michaelson RA, Girish S et al (2011) Phase II study of the antibody drug conjugate trastuzumabDM1 for the treatment of human epidermal growth factor receptor 2 (HER2)-positive breast cancer after prior HER2-directed therapy. J Clin Oncol 29:398-405

26. Lippert TH, Ruoff HJ, Volm M (2008) Intrinsic and acquired drug resistance in malignant tumors. The main reason for therapeutic failure. Arzneim Forsch 58:261-264

27. Gottesman MM (2002) Mechanisms of cancer drug resistance. Annu Rev Med 53:615-627

28. Dhillon KK, Swisher EM, Taniguchi T (2011) Secondary mutations of BRCA1/2 and drug resistance. Cancer Sci 102:663-669

29. Zhou Q, Lv H, Mazloom AR, Xu H, Ma'ayan A, Gallo JM (2012) Activation of alternate prosurvival pathways accounts for acquired sunitinib resistance in U87MG glioma xenografts. J Pharm Exp Ther 343:509-519

30. Blower PE, Chung JH, Verducci JS, Lin S, Park JK, Dai Z, Liu CG, Schmittgen TD, Reinhold WC, Croce CM et al (2008) MicroRNAs modulate the chemosensitivity of tumor cells. Mol Cancer Ther 7:1-9

31. Cai J, Yang C, Yang Q, Ding H, Jia J, Guo J, Wang J, Wang Z (2013) Deregulation of let-7e in epithelial ovarian cancer promotes the development of resistance to cisplatin. Oncogenesis 2:e75

32. Weeraratne SD, Amani V, Neiss A, Teider N, Scott DK, Pomeroy SL, Cho YJ (2011) miR-34a confers chemosensitivity through modulation of MAGE-A and p53 in medulloblastoma. Neuro Oncol 13:165-175

33. Takwi AA, Wang YM, Wu J, Michaelis M, Cinatl J, Chen T (2013) miR-137 regulates the constitutive androstane receptor and modulates doxorubicin sensitivity in parental and doxorubicin-resistant neuroblastoma cells. Oncogene. doi:10.1038/onc.2013.330

34. Pouliot LM, Shen DW, Suzuki T, Hall MD, Gottesman MM (2013) Contributions of microRNA dysregulation to cisplatin resistance in adenocarcinoma cells. Exp Cell Res 319:566-574

35. Druker BJ (2003) Imatinib mesylate in the treatment of chronic myeloid leukaemia. Expert Opin Pharmacother 4:963-971

36. Xu C, Fu H, Gao L, Wang L, Wang W, Li J, Li Y, Dou L, Gao X, Luo $X$ et al (2012) BCR-ABL/GATA1/miR-138 mini circuitry contributes to the leukemogenesis of chronic myeloid leukemia. Oncogene 33:44-54

37. Li Y, Yuan Y, Tao K, Wang X, Xiao Q, Huang Z, Zhong L, Cao W, Wen J, Feng W (2013) Inhibition of BCR/ABL protein expression by miR-203 sensitizes for imatinib mesylate. PLoS ONE 8:e61858

38. Gong C, Yao Y, Wang Y, Liu B, Wu W, Chen J, Su F, Yao H, Song E (2011) Up-regulation of miR-21 mediates resistance to trastuzumab therapy for breast cancer. J Biol Chem 286:19127-19137
39. Jung EJ, Santarpia L, Kim J, Esteva FJ, Moretti E, Buzdar AU, Di Leo A, Le XF, Bast RC Jr, Park ST et al (2012) Plasma microRNA 210 levels correlate with sensitivity to trastuzumab and tumor presence in breast cancer patients. Cancer 118:2603-2614

40. Zhao JJ, Lin J, Yang H, Kong W, He L, Ma X, Coppola D, Cheng JQ (2008) MicroRNA-221/222 negatively regulates estrogen receptor alpha and is associated with tamoxifen resistance in breast cancer. J Biol Chem 283:31079-31086

41. Miller TE, Ghoshal K, Ramaswamy B, Roy S, Datta J, Shapiro CL, Jacob S, Majumder S (2008) MicroRNA-221/222 confers tamoxifen resistance in breast cancer by targeting p27Kip1. J Biol Chem 283:29897-29903

42. Rao X, Di Leva G, Li M, Fang F, Devlin C, Hartman-Frey C, Burow ME, Ivan M, Croce CM, Nephew KP (2011) MicroRNA-221/222 confers breast cancer fulvestrant resistance by regulating multiple signaling pathways. Oncogene 30:1082-1097

43. Ward A, Balwierz A, Zhang JD, Kublbeck M, Pawitan Y, Hielscher T, Wiemann S, Sahin O (2013) Re-expression of microRNA-375 reverses both tamoxifen resistance and accompanying EMT-like properties in breast cancer. Oncogene 32:1173-1182

44. Fidler IJ (2003) The pathogenesis of cancer metastasis: the 'seed and soil' hypothesis revisited. Nat Rev Cancer 3:453-458

45. Dykxhoorn DM (2010) MicroRNAs and metastasis: little RNAs go a long way. Cancer Res 70:6401-6406

46. Tao ZH, Wan JL, Zeng LY, Xie L, Sun HC, Qin LX, Wang L, Zhou J, Ren ZG, Li YX et al (2013) miR-612 suppresses the invasivemetastatic cascade in hepatocellular carcinoma. J Exp Med 210: 789-803

47. Polyak K, Weinberg RA (2009) Transitions between epithelial and mesenchymal states: acquisition of malignant and stem cell traits. Nat Rev Cancer 9:265-273

48. Gibbons DL, Lin W, Creighton CJ, Rizvi ZH, Gregory PA, Goodall GJ, Thilaganathan N, Du L, Zhang Y, Pertsemlidis A et al (2009) Contextual extracellular cues promote tumor cell EMT and metastasis by regulating miR-200 family expression. Genes Dev 23: 2140-2151

49. Olson P, Lu J, Zhang H, Shai A, Chun MG, Wang Y, Libutti SK, Nakakura EK, Golub TR, Hanahan D (2009) MicroRNA dynamics in the stages of tumorigenesis correlate with hallmark capabilities of cancer. Genes Dev 23:2152-2165

50. Bracken CP, Gregory PA, Kolesnikoff N, Bert AG, Wang J, Shannon MF, Goodall GJ (2008) A double-negative feedback loop between ZEB1-SIP1 and the microRNA-200 family regulates epithelial-mesenchymal transition. Cancer Res 68:7846-7854

51. Burk U, Schubert J, Wellner U, Schmalhofer O, Vincan E, Spaderna S, Brabletz T (2008) A reciprocal repression between ZEB1 and members of the miR-200 family promotes EMT and invasion in cancer cells. EMBO Rep 9:582-589

52. Kim NH, Kim HS, Li XY, Lee I, Choi HS, Kang SE, Cha SY, Ryu JK, Yoon D, Fearon ER et al (2011) A p53/miRNA-34 axis regulates Snaill-dependent cancer cell epithelial-mesenchymal transition. J Cell Biol 195:417-433

53. Siemens H, Jackstadt R, Hunten S, Kaller M, Menssen A, Gotz U, Hermeking H (2011) miR-34 and SNAIL form a double-negative feedback loop to regulate epithelial-mesenchymal transitions. Cell Cycle 10:4256-4271

54. Jurmeister S, Baumann M, Balwierz A, Keklikoglou I, Ward A, Uhlmann S, Zhang JD, Wiemann S, Sahin O (2012) MicroRNA200c represses migration and invasion of breast cancer cells by targeting actin-regulatory proteins FHOD1 and PPM1F. Mol Cell Biol 32:633-651

55. Li X, Roslan S, Johnstone CN, Wright JA, Bracken CP, Anderson M, Bert AG, Selth LA, Anderson RL, Goodall GJ et al (2013) MiR200 can repress breast cancer metastasis through ZEB1-independent but moesin-dependent pathways. Oncogene. doi:10.1038/onc.2013. 370 
56. Asangani IA, Rasheed SA, Nikolova DA, Leupold JH, Colburn NH, Post S, Allgayer H (2008) MicroRNA-21 (miR-21) posttranscriptionally downregulates tumor suppressor Pdcd4 and stimulates invasion, intravasation and metastasis in colorectal cancer. Oncogene 27:2128-2136

57. Valastyan S, Chang A, Benaich N, Reinhardt F, Weinberg RA (2010) Concurrent suppression of integrin alpha5, radixin, and RhoA phenocopies the effects of miR-31 on metastasis. Cancer Res 70:5147-5154

58. Okamoto $\mathrm{K}$, Ishiguro $\mathrm{T}$, Midorikawa $\mathrm{Y}$, Ohata $\mathrm{H}$, Izumiya $\mathrm{M}$, Tsuchiya N, Sato A, Sakai H, Nakagama H (2012) miR-493 induction during carcinogenesis blocks metastatic settlement of colon cancer cells in liver. EMBO J 31:1752-1763

59. Cimino D, De Pitta C, Orso F, Zampini M, Casara S, Penna E, Quaglino E, Forni M, Damasco C, Pinatel E et al (2013) miR148b is a major coordinator of breast cancer progression in a relapseassociated microRNA signature by targeting ITGA5, ROCK1, PIK3CA, NRAS, and CSF1. FASEB J 27:1223-1235

60. Keklikoglou I, Koerner C, Schmidt C, Zhang JD, Heckmann D, Shavinskaya A, Allgayer H, Guckel B, Fehm T, Schneeweiss A et al (2012) MicroRNA-520/373 family functions as a tumor suppressor in estrogen receptor negative breast cancer by targeting NFkappaB and TGF-beta signaling pathways. Oncogene 31:41504163

61. Nguyen DX, Bos PD, Massague J (2009) Metastasis: from dissemination to organ-specific colonization. Nat Rev Cancer 9:274-284

62. Korpal M, Ell BJ, Buffa FM, Ibrahim T, Blanco MA, Celia-Terrassa T, Mercatali L, Khan Z, Goodarzi H, Hua Y et al (2011) Direct targeting of Sec23a by miR-200 s influences cancer cell secretome and promotes metastatic colonization. Nat Med 17:1101-1108

63. Liu S, Tetzlaff MT, Cui R, Xu X (2012) miR-200c inhibits melanoma progression and drug resistance through down-regulation of BMI-1. Am J Pathol 181:1823-1835

64. Ceppi P, Mudduluru G, Kumarswamy R, Rapa I, Scagliotti GV, Papotti M, Allgayer H (2010) Loss of miR-200c expression induces an aggressive, invasive, and chemoresistant phenotype in non-small cell lung cancer. Mol Cancer Res 8:1207-1216

65. Li Y, VandenBoom TG 2nd, Kong D, Wang Z, Ali S, Philip PA, Sarkar FH (2009) Up-regulation of miR-200 and let-7 by natural agents leads to the reversal of epithelial-to-mesenchymal transition in gemcitabineresistant pancreatic cancer cells. Cancer Res 69:6704-6712

66. Cao M, Seike M, Soeno C, Mizutani H, Kitamura K, Minegishi Y, Noro R, Yoshimura A, Cai L, Gemma A (2012) MiR-23a regulates TGF-beta-induced epithelial-mesenchymal transition by targeting E-cadherin in lung cancer cells. Int J Oncol 41:869-875

67. Xia H, Ooi LL, Hui KM (2013) MicroRNA-216a/217-induced epithelial-mesenchymal transition targets PTEN and SMAD7 to promote drug resistance and recurrence of liver cancer. Hepatology 58:629-641

68. Weissman IL (2000) Stem cells: units of development, units of regeneration, and units in evolution. Cell 100:157-168

69. Stingl J, Eirew P, Ricketson I, Shackleton M, Vaillant F, Choi D, Li HI, Eaves CJ (2006) Purification and unique properties of mammary epithelial stem cells. Nature 439:993-997

70. Beltrami AP, Barlucchi L, Torella D, Baker M, Limana F, Chimenti S, Kasahara H, Rota M, Musso E, Urbanek K et al (2003) Adult cardiac stem cells are multipotent and support myocardial regeneration. Cell 114:763-776

71. Bonnet D, Dick JE (1997) Human acute myeloid leukemia is organized as a hierarchy that originates from a primitive hematopoietic cell. Nat Med 3:730-737

72. Li C, Heidt DG, Dalerba P, Burant CF, Zhang L, Adsay V, Wicha M, Clarke MF, Simeone DM (2007) Identification of pancreatic cancer stem cells. Cancer Res 67:1030-1037

73. Maitland NJ, Collins AT (2008) Prostate cancer stem cells: a new target for therapy. J Clin Oncol Off J Am Soc Clin Oncol 26:2862-2870
74. O'Brien CA, Pollett A, Gallinger S, Dick JE (2007) A human colon cancer cell capable of initiating tumour growth in immunodeficient mice. Nature 445:106-110

75. Singh SK, Clarke ID, Terasaki M, Bonn VE, Hawkins C, Squire J, Dirks PB (2003) Identification of a cancer stem cell in human brain tumors. Cancer Res 63:5821-5828

76. Al-Hajj M, Wicha MS, Benito-Hernandez A, Morrison SJ, Clarke MF (2003) Prospective identification of tumorigenic breast cancer cells. Proc Natl Acad Sci U S A 100:3983-3988

77. Yilmaz OH, Valdez R, Theisen BK, Guo W, Ferguson DO, Wu H, Morrison SJ (2006) Pten dependence distinguishes haematopoietic stem cells from leukaemia-initiating cells. Nature 441:475-482

78. Quintana E, Shackleton M, Sabel MS, Fullen DR, Johnson TM, Morrison SJ (2008) Efficient tumour formation by single human melanoma cells. Nature 456:593-598

79. Xu XT, Xu Q, Tong JL, Zhu MM, Nie F, Chen X, Xiao SD, Ran ZH (2012) MicroRNA expression profiling identifies miR-328 regulates cancer stem cell-like SP cells in colorectal cancer. Br J Cancer 106:1320-1330

80. Shimono Y, Zabala M, Cho RW, Lobo N, Dalerba P, Qian D, Diehn M, Liu H, Panula SP, Chiao E et al (2009) Downregulation of miRNA-200c links breast cancer stem cells with normal stem cells. Cell 138:592-603

81. Ju SY, Chiou SH, Su Y (2013) Maintenance of the stemness in CD44 HCT-15 and HCT-116 human colon cancer cells requires miR-203 suppression. Stem Cell Res 12:86-100

82. Golestaneh AF, Atashi A, Langroudi L, Shafiee A, Ghaemi N, Soleimani M (2012) miRNAs expressed differently in cancer stem cells and cancer cells of human gastric cancer cell line MKN-45. Cell Biochem Funct 30:411-418

83. Ji J, Yamashita T, Budhu A, Forgues M, Jia HL, Li C, Deng C, Wauthier E, Reid LM, Ye QH et al (2009) Identification of microRNA-181 by genome-wide screening as a critical player in EpCAM-positive hepatic cancer stem cells. Hepatology 50:472-480

84. Yu Y, Kanwar SS, Patel BB, Oh PS, Nautiyal J, Sarkar FH, Majumdar AP (2012) MicroRNA-21 induces stemness by downregulating transforming growth factor beta receptor 2 (TGFbetaR2) in colon cancer cells. Carcinogenesis 33:68-76

85. Li F, Tiede B, Massague J, Kang Y (2007) Beyond tumorigenesis: cancer stem cells in metastasis. Cell Res 17:3-14

86. Xu CX, Xu M, Tan L, Yang H, Permuth-Wey J, Kruk PA, Wenham RM, Nicosia SV, Lancaster JM, Sellers TA et al (2012) MicroRNA miR-214 regulates ovarian cancer cell stemness by targeting p53/ Nanog. J Biol Chem 287:34970-34978

87. Bourguignon LY, Wong G, Earle C, Chen L (2012) HyaluronanCD44v3 interaction with Oct4-Sox2-Nanog promotes miR-302 expression leading to self-renewal, clonal formation, and cisplatin resistance in cancer stem cells from head and neck squamous cell carcinoma. J Biol Chem 287:32800-32824

88. Bitarte N, Bandres E, Boni V, Zarate R, Rodriguez J, GonzalezHuarriz M, Lopez I, Javier Sola J, Alonso MM, Fortes P et al (2011) MicroRNA-451 is involved in the self-renewal, tumorigenicity, and chemoresistance of colorectal cancer stem cells. Stem Cells 29: 1661-1671

89. Bao B, Ali S, Kong D, Sarkar SH, Wang Z, Banerjee S, Aboukameel A, Padhye S, Philip PA, Sarkar FH (2011) Antitumor activity of a novel compound-CDF is mediated by regulating miR-21, miR-200, and PTEN in pancreatic cancer. PLoS ONE 6: e17850

90. Bao B, Wang Z, Ali S, Ahmad A, Azmi AS, Sarkar SH, Banerjee S, Kong D, Li Y, Thakur S et al (2012) Metformin inhibits cell proliferation, migration and invasion by attenuating CSC function mediated by deregulating miRNAs in pancreatic cancer cells. Cancer Prev Res (Phila) 5:355-364

91. Lo WL, Yu CC, Chiou GY, Chen YW, Huang PI, Chien CS, Tseng LM, Chu PY, Lu KH, Chang KW et al (2011) MicroRNA-200c 
attenuates tumour growth and metastasis of presumptive head and neck squamous cell carcinoma stem cells. J Pathol 223:482-495

92. Wellner U, Schubert J, Burk UC, Schmalhofer O, Zhu F, Sonntag A, Waldvogel B, Vannier C, Darling D, zur Hausen A et al (2009) The EMT-activator ZEB1 promotes tumorigenicity by repressing stemness-inhibiting microRNAs. Nat Cell Biol 11:1487-1495

93. Okuda H, Xing F, Pandey PR, Sharma S, Watabe M, Pai SK, Mo YY, Iiizumi-Gairani M, Hirota S, Liu Y et al (2013) miR-7 suppresses brain metastasis of breast cancer stem-like cells by modulating KLF4. Cancer Res 73:1434-1444

94. Liu C, Kelnar K, Liu B, Chen X, Calhoun-Davis T, Li H, Patrawala L, Yan H, Jeter C, Honorio S et al (2011) The microRNA miR-34a inhibits prostate cancer stem cells and metastasis by directly repressing CD44. Nat Med 17:211-215

95. Song SJ, Poliseno L, Song MS, Ala U, Webster K, Ng C, Beringer G, Brikbak NJ, Yuan X, Cantley LC et al (2013) MicroRNAantagonism regulates breast cancer stemness and metastasis via TET-family-dependent chromatin remodeling. Cell 154:311-324

96. Iliou MS, da Silva-Diz V, Carmona FJ, Ramalho-Carvalho J, Heyn H, Villanueva A, Munoz P, Esteller M (2013) Impaired DICER1 function promotes stemness and metastasis in colon cancer. Oncogene. doi:10.1038/onc.2013.398

97. Pencheva N, Tavazoie SF (2013) Control of metastatic progression by microRNA regulatory networks. Nat Cell Biol 15:546-554

98. Vera J, Lai X, Schmitz U, Wolkenhauer O (2013) MicroRNAregulated networks: the perfect storm for classical molecular biology, the ideal scenario for systems biology. Adv Exp Med Biol 774: $55-76$

99. Aguda BD, Kim Y, Piper-Hunter MG, Friedman A, Marsh CB (2008) MicroRNA regulation of a cancer network: consequences of the feedback loops involving miR-17-92, E2F, and Myc. Proc Natl Acad Sci U S A 105:19678-19683

100. Vera J, Schmitz U, Lai X, Engelmann D, Khan FM, Wolkenhauer O, Putzer BM (2013) Kinetic modeling-based detection of genetic signatures that provide chemoresistance via the E2F1-p73/DNp73miR-205 network. Cancer Res 73:3511-3524

101. Prosser HM, Koike-Yusa H, Cooper JD, Law FC, Bradley A (2011) A resource of vectors and ES cells for targeted deletion of microRNAs in mice. Nature Biotechnol 29:840-845

102. Ye H, Liu X, Lv M, Wu Y, Kuang S, Gong J, Yuan P, Zhong Z, Li Q, Jia $\mathrm{H}$ et al (2012) MicroRNA and transcription factor co-regulatory network analysis reveals miR-19 inhibits CYLD in T-cell acute lymphoblastic leukemia. Nucleic Acids Res 40:5201-5214

103. Ding X, Park SI, McCauley LK, Wang CY (2013) Signaling between transforming growth factor beta (TGF-beta) and transcription factor SNAI2 represses expression of microRNA miR-203 to promote epithelial-mesenchymal transition and tumor metastasis. J Biol Chem 288:10241-10253

104. Uhlmann S, Zhang JD, Schwager A, Mannsperger H, Riazalhosseini Y, Burmester S, Ward A, Korf U, Wiemann S, Sahin O (2010) miR-200bc/429 cluster targets PLCgammal and differentially regulates proliferation and EGF-driven invasion than miR-200a/141 in breast cancer. Oncogene 29:4297-4306

105. Tarasov V, Jung P, Verdoodt B, Lodygin D, Epanchintsev A, Menssen A, Meister G, Hermeking H (2007) Differential regulation of microRNAs by p 53 revealed by massively parallel sequencing: miR-34a is a p53 target that induces apoptosis and G1-arrest. Cell Cycle 6:1586-1593

106. Leivonen SK, Rokka A, Ostling P, Kohonen P, Corthals GL, Kallioniemi O, Perala M (2011) Identification of miR-193b targets in breast cancer cells and systems biological analysis of their functional impact. Mol Cell Proteomics 10(M110):005322

107. Baek D, Villen J, Shin C, Camargo FD, Gygi SP, Bartel DP (2008) The impact of microRNAs on protein output. Nature 455:64-71

108. Li L, Xu J, Yang D, Tan X, Wang H (2010) Computational approaches for microRNA studies: a review. Mamm Genome 21:1-12
109. Min H, Yoon S (2010) Got target? Computational methods for microRNA target prediction and their extension. Exp Mol Med 42:233-244

110. Uhlmann S, Mannsperger H, Zhang JD, Horvat EA, Schmidt C, Kublbeck M, Henjes F, Ward A, Tschulena U, Zweig K et al (2012) Global microRNA level regulation of EGFR-driven cell-cycle protein network in breast cancer. Mol Syst Biol 8:570

111. Yu Z, Willmarth NE, Zhou J, Katiyar S, Wang M, Liu Y, McCue PA, Quong AA, Lisanti MP, Pestell RG (2010) microRNA 17/20 inhibits cellular invasion and tumor metastasis in breast cancer by heterotypic signaling. Proc Natl Acad Sci U S A 107:8231-8236

112. Volinia S, Galasso M, Costinean S, Tagliavini L, Gamberoni G, Drusco A, Marchesini J, Mascellani N, Sana ME, Abu Jarour R et al (2010) Reprogramming of miRNA networks in cancer and leukemia. Genome Res 20:589-599

113. Png KJ, Halberg N, Yoshida M, Tavazoie SF (2012) A microRNA regulon that mediates endothelial recruitment and metastasis by cancer cells. Nature 481:190-194

114. Hafner M, Landthaler M, Burger L, Khorshid M, Hausser J, Berninger $\mathrm{P}$, Rothballer A, Ascano M Jr, Jungkamp AC, Munschauer $M$ et al (2010) Transcriptome-wide identification of RNA-binding protein and microRNA target sites by PAR-CLIP. Cell 141:129-141

115. Nilsson T, Mann M, Aebersold R, Yates JR 3rd, Bairoch A, Bergeron JJ (2010) Mass spectrometry in high-throughput proteomics: ready for the big time. Nat methods 7:681-685

116. Sumazin P, Yang X, Chiu HS, Chung WJ, Iyer A, Llobet-Navas D, Rajbhandari P, Bansal M, Guarnieri P, Silva J et al (2011) An extensive microRNA-mediated network of RNA-RNA interactions regulates established oncogenic pathways in glioblastoma. Cell 147:370-381

117. Zacher B, Abnaof K, Gade S, Younesi E, Tresch A, Frohlich H (2012) Joint Bayesian inference of condition-specific miRNA and transcription factor activities from combined gene and microRNA expression data. Bioinformatics 28:1714-1720

118. Liu Y, Devescovi V, Chen S, Nardini C (2013) Multilevel omic data integration in cancer cell lines: advanced annotation and emergent properties. BMC Syst Biol 7:14

119. Rohr C, Kerick M, Fischer A, Kuhn A, Kashofer K, Timmermann B, Daskalaki A, Meinel T, Drichel D, Borno ST et al (2013) Highthroughput miRNA and mRNA sequencing of paired colorectal normal, tumor and metastasis tissues and bioinformatic modeling of miRNA-1 therapeutic applications. PLoS ONE 8:e67461

120. Barabasi AL, Oltvai ZN (2004) Network biology: understanding the cell's functional organization. Nat Rev Genet 5:101-113

121. Barabasi AL, Gulbahce N, Loscalzo J (2011) Network medicine: a network-based approach to human disease. Nat Rev Genet 12:56-68

122. Alon U (2007) Network motifs: theory and experimental approaches. Nat Rev Genet 8:450-461

123. Zhang HM, Kuang S, Xiong X, Gao T, Liu C, Guo AY (2013) Transcription factor and microRNA co-regulatory loops: important regulatory motifs in biological processes and diseases. Brief Bioinform. doi:10.1093/bib/bbt085

124. Zhang KL, Han L, Chen LY, Shi ZD, Yang M, Ren Y, Chen LC, Zhang JX, Pu PY, Kang CS (2014) Blockage of a miR-21/EGFR regulatory feedback loop augments anti-EGFR therapy in glioblastomas. Cancer Lett 342:139-149

125. Zhao X, Lwin T, Zhang X, Huang A, Wang J, Marquez VE, ChenKiang S, Dalton WS, Sotomayor E, Tao J (2013) Disruption of the MYC-miRNA-EZH2 loop to suppress aggressive B-cell lymphoma survival and clonogenicity. Leukemia. doi:10.1038/leu.2013.94

126. Rukov JL, Wilentzik R, Jaffe I, Vinther J, Shomron N (2013) Pharmaco-miR: linking microRNAs and drug effects. Brief Bioinform. doi:10.1093/bib/bbs082

127. Jiang Q, Wang Y, Hao Y, Juan L, Teng M, Zhang X, Li M, Wang G, Liu Y (2009) miR2Disease: a manually curated database for microRNA deregulation in human disease. Nucleic Acids Res 37:D98-D104 
128. Pardo-Martin C, Chang TY, Koo BK, Gilleland CL, Wasserman SC, Yanik MF (2010) High-throughput in vivo vertebrate screening. Nat Methods 7:634-636

129. Garzon R, Marcucci G, Croce CM (2010) Targeting microRNAs in cancer: rationale, strategies and challenges. Nat Rev Drug Discov 9: 775-789

130. Hutvagner G, Simard MJ, Mello CC, Zamore PD (2004) Sequencespecific inhibition of small RNA function. PLoS Biol 2:E98

131. Krutzfeldt J, Rajewsky N, Braich R, Rajeev KG, Tuschl T, Manoharan M, Stoffel M (2005) Silencing of microRNAs in vivo with 'antagomirs'. Nature 438:685-689

132. Zhang Y, Roccaro AM, Rombaoa C, Flores L, Obad S, Fernandes SM, Sacco A, Liu Y, Ngo H, Quang P et al (2012) LNA-mediated anti-miR-155 silencing in low-grade B-cell lymphomas. Blood 120: $1678-1686$

133. Esquela-Kerscher A, Trang P, Wiggins JF, Patrawala L, Cheng A, Ford L, Weidhaas JB, Brown D, Bader AG, Slack FJ (2008) The let7 microRNA reduces tumor growth in mouse models of lung cancer. Cell Cycle 7:759-764

134. Xiong Y, Fang JH, Yun JP, Yang J, Zhang Y, Jia WH, Zhuang SM (2010) Effects of microRNA-29 on apoptosis, tumorigenicity, and prognosis of hepatocellular carcinoma. Hepatology 51:836-845

135. Ell B, Mercatali L, Ibrahim T, Campbell N, Schwarzenbach H, Pantel K, Amadori D, Kang Y (2013) Tumor-Induced Osteoclast miRNA Changes as Regulators and Biomarkers of Osteolytic Bone Metastasis. Cancer Cell 24:542-556

136. Gumireddy K, Young DD, Xiong X, Hogenesch JB, Huang Q, Deiters A (2008) Small-molecule inhibitors of microrna miR-21 function. Angew Chem Int Ed Engl 47:7482-7484

137. Kota J, Chivukula RR, O'Donnell KA, Wentzel EA, Montgomery CL, Hwang HW, Chang TC, Vivekanandan P, Torbenson M, Clark KR et al (2009) Therapeutic microRNA delivery suppresses tumorigenesis in a murine liver cancer model. Cell 137:1005-1017

138. Kumar MS, Erkeland SJ, Pester RE, Chen CY, Ebert MS, Sharp PA, Jacks T (2008) Suppression of non-small cell lung tumor development by the let-7 microRNA family. Proc Natl Acad Sci U S A 105: 3903-3908

139. Zhang Y, Wang Z, Gemeinhart RA (2013) Progress in microRNA delivery. J Control Release 172:962-974

140. Piao L, Zhang M, Datta J, Xie X, Su T, Li H, Teknos TN, Pan Q (2012) Lipid-based nanoparticle delivery of Pre-miR-107 inhibits the tumorigenicity of head and neck squamous cell carcinoma. Mol Ther 20:1261-1269

141. Babar IA, Cheng CJ, Booth CJ, Liang X, Weidhaas JB, Saltzman WM, Slack FJ (2012) Nanoparticle-based therapy in an in vivo microRNA-155 (miR-155)-dependent mouse model of lymphoma. Proc Natl Acad Sci U S A 109:E1695-E1704

142. Ohno S, Takanashi M, Sudo K, Ueda S, Ishikawa A, Matsuyama N, Fujita K, Mizutani T, Ohgi T, Ochiya T et al (2013) Systemically injected exosomes targeted to EGFR deliver antitumor microRNA to breast cancer cells. Mol Ther 21:185-191

143. van Miltenburg MH, Jonkers J (2012) Using genetically engineered mouse models to validate candidate cancer genes and test new therapeutic approaches. Curr Opin Genet Dev 22:21-27

144. Landis MD, Lehmann BD, Pietenpol JA, Chang JC (2013) Patientderived breast tumor xenografts facilitating personalized cancer therapy. Breast Cancer Res 15:201

145. Zhang J, Ma L (2012) MicroRNA control of epithelial-mesenchymal transition and metastasis. Cancer Metastasis Rev 31:653-662

146. Clarke MF, Dick JE, Dirks PB, Eaves CJ, Jamieson CH, Jones DL, Visvader J, Weissman IL, Wahl GM (2006) Cancer stem cellsperspectives on current status and future directions: AACR Workshop on cancer stem cells. Cancer Res 66:9339-9344

147. Horvat EA, Zhang JD, Uhlmann S, Sahin O, Zweig KA (2013) A network-based method to assess the statistical significance of mild co-regulation effects. PLoS ONE 8:e73413
148. Mitchell PS, Parkin RK, Kroh EM, Fritz BR, Wyman SK, Pogosova-Agadjanyan EL, Peterson A, Noteboom J, O'Briant KC, Allen A et al (2008) Circulating microRNAs as stable bloodbased markers for cancer detection. Proc Natl Acad Sci U S A 105: 10513-10518

149. Chen X, Ba Y, Ma L, Cai X, Yin Y, Wang K, Guo J, Zhang Y, Chen J, Guo X et al (2008) Characterization of microRNAs in serum: a novel class of biomarkers for diagnosis of cancer and other diseases. Cell Res 18:997-1006

150. Kitamura K, Seike M, Okano T, Matsuda K, Miyanaga A, Mizutani H, Noro R, Minegishi Y, Kubota K, Gemma A (2013) MiR-134/ 487b/655 Cluster Regulates TGF-beta-induced EpithelialMesenchymal Transition and Drug Resistance to Gefitinib by Targeting MAGI2 in Lung Adenocarcinoma Cells. Mol Cancer Ther. doi:10.1158/1535-7163.MCT-13-0448

151. Chang CJ, Hsu CC, Chang CH, Tsai LL, Chang YC, Lu SW, Yu $\mathrm{CH}$, Huang HS, Wang JJ, Tsai CH et al (2011) Let-7d functions as novel regulator of epithelial-mesenchymal transition and chemoresistant property in oral cancer. Oncol Rep 26:1003-1010

152. Vaira V, Faversani A, Martin NM, Garlick DS, Ferrero S, Nosotti M, Kissil JL, Bosari S, Altieri DC (2013) Regulation of lung cancer metastasis by Klf4-Numb-like signaling. Cancer Res 73:2695-2705

153. Ren D, Wang M, Guo W, Zhao X, Tu X, Huang S, Zou X, Peng X (2013) Wild-type p53 suppresses the epithelial-mesenchymal transition and stemness in PC-3 prostate cancer cells by modulating miR145. Int J Oncol 42:1473-1481

154. Han M, Wang Y, Liu M, Bi X, Bao J, Zeng N, Zhu Z, Mo Z, Wu C, Chen X (2012) MiR-21 regulates epithelial-mesenchymal transition phenotype and hypoxia-inducible factor-1alpha expression in thirdsphere forming breast cancer stem cell-like cells. Cancer Sci 103: $1058-1064$

155. Fan X, Chen X, Deng W, Zhong G, Cai Q, Lin T (2013) Upregulated microRNA-143 in cancer stem cells differentiation promotes prostate cancer cells metastasis by modulating FNDC3B expression. BMC Cancer 13:61

156. Chiou GY, Cherng JY, Hsu HS, Wang ML, Tsai CM, Lu KH, Chien Y, Hung SC, Chen YW, Wong CI et al (2012) Cationic polyurethanes-short branch PEI-mediated delivery of Mir145 inhibited epithelial-mesenchymal transdifferentiation and cancer stem-like properties and in lung adenocarcinoma. J Control Release 159:240-250

157. Guttilla IK, Phoenix KN, Hong X, Tirnauer JS, Claffey KP, White BA (2012) Prolonged mammosphere culture of MCF-7 cells induces an EMT and repression of the estrogen receptor by microRNAs. Breast Cancer Res Treat 132:75-85

158. Yang YP, Chien Y, Chiou GY, Cherng JY, Wang ML, Lo WL, Chang YL, Huang PI, Chen YW, Shih YH et al (2012) Inhibition of cancer stem cell-like properties and reduced chemoradioresistance of glioblastoma using microRNA145 with cationic polyurethane-short branch PEI. Biomaterials 33:14621476

159. Jeon HM, Sohn YW, Oh SY, Kim SH, Beck S, Kim S, Kim H (2011) ID4 imparts chemoresistance and cancer stemness to glioma cells by derepressing miR-9*-mediated suppression of SOX2. Cancer Res 71:3410-3421

160. Cheng W, Liu T, Wan X, Gao Y, Wang H (2012) MicroRNA-199a targets CD44 to suppress the tumorigenicity and multidrug resistance of ovarian cancer-initiating cells. FEBS J 279:2047-2059

161. Yu CC, Chen YW, Chiou GY, Tsai LL, Huang PI, Chang CY, Tseng LM, Chiou SH, Yen SH, Chou MY et al (2011) MicroRNA let-7a represses chemoresistance and tumourigenicity in head and neck cancer via stem-like properties ablation. Oral Oncol 47:202-210

162. Nakajima G, Hayashi K, Xi Y, Kudo K, Uchida K, Takasaki K, Yamamoto M, Ju J (2006) Non-coding MicroRNAs hsa-let-7 g and hsa-miR-181b are Associated with Chemoresponse to S-1 in Colon Cancer. Cancer Genomics Proteomics 3:317-324 
163. Tong JL, Zhang CP, Nie F, Xu XT, Zhu MM, Xiao SD, Ran ZH (2011) MicroRNA 506 regulates expression of PPAR alpha in hydroxycamptothecin-resistant human colon cancer cells. FEBS Lett 585:3560-3568

164. Ragusa M, Majorana A, Statello L, Maugeri M, Salito L, Barbagallo D, Guglielmino MR, Duro LR, Angelica R, Caltabiano R (2010) Specific alterations of microRNA transcriptome and global network structure in colorectal carcinoma after cetuximab treatment. Mol Cancer Ther 9:3396-3409

165. Ru P, Steele R, Hsueh EC, Ray RB (2011) Anti-miR-203 Upregulates SOCS3 Expression in Breast Cancer Cells and Enhances Cisplatin Chemosensitivity. Genes Cancer 2:720-727

166. Kovalchuk O, Filkowski J, Meservy J, Inytskyy Y, Tryndyak VP, Chekhun VF, Pogribny IP (2008) Involvement of microRNA-451 in resistance of the MCF-7 breast cancer cells to chemotherapeutic drug doxorubicin. Mol Cancer Ther 7:2152-2159

167. Kalinowski FC, Giles KM, Candy PA, Ali A, Ganda C, Epis MR, Webster RJ, Leedman PJ (2012) Regulation of epidermal growth factor receptor signaling and erlotinib sensitivity in head and neck cancer cells by miR-7. PLoS ONE 7:e47067

168. Chen G, Umelo IA, Lv S, Teugels E, Fostier K, Kronenberger P, Dewaele A, Sadones J, Geers C, De Greve J (2013) miR-146a inhibits cell growth, cell migration and induces apoptosis in nonsmall cell lung cancer cells. PLoS ONE 8:e60317

169. Masri S, Liu Z, Phung S, Wang E, Yuan YC, Chen S (2010) The role of microRNA-128a in regulating TGFbeta signaling in letrozoleresistant breast cancer cells. Breast Cancer Res Treat 124:89-99

170. Pan YZ, Morris ME, Yu AM (2009) MicroRNA-328 negatively regulates the expression of breast cancer resistance protein (BCRP/ABCG2) in human cancer cells. Mol Pharmacol 75:1374 1379

171. Sorrentino A, Liu CG, Addario A, Peschle C, Scambia G, Ferlini C (2008) Role of microRNAs in drug-resistant ovarian cancer cells. Gynecol Oncol 111:478-486

172. Costa PM, Cardoso AL, Nobrega C, Pereira de Almeida LF, Bruce JN, Canoll P, Pedroso de Lima MC (2013) MicroRNA-21 silencing enhances the cytotoxic effect of the antiangiogenic drug sunitinib in glioblastoma. Hum Mol Genet 22:904-918

173. Berkers J, Govaere O, Wolter P, Beuselinck B, Schoffski P, van Kempen LC, Albersen M, Van den Oord J, Roskams T, Swinnen J et al (2013) A possible role for microRNA-141 down-regulation in sunitinib resistant metastatic clear cell renal cell carcinoma through induction of epithelial-to-mesenchymal transition and hypoxia resistance. J Urol 189:1930-1938

174. Zhu H, Wu H, Liu X, Evans BR, Medina DJ, Liu CG, Yang JM (2008) Role of MicroRNA miR-27a and miR-451 in the regulation of MDR1/P-glycoprotein expression in human cancer cells. Biochem Pharmacol 76:582-588

175. Chou J, Lin JH, Brenot A, Kim JW, Provot S, Werb Z (2013) GATA3 suppresses metastasis and modulates the tumour microenvironment by regulating microRNA-29b expression. Nat Cell Biol 15:201-213

176. Fang JH, Zhou HC, Zeng C, Yang J, Liu Y, Huang X, Zhang JP, Guan XY, Zhuang SM (2011) MicroRNA-29b suppresses tumor angiogenesis, invasion, and metastasis by regulating matrix metalloproteinase 2 expression. Hepatology 54:1729-1740

177. Kumarswamy R, Mudduluru G, Ceppi P, Muppala S, Kozlowski M, Niklinski J, Papotti M, Allgayer H (2012) MicroRNA-30a inhibits epithelial-to-mesenchymal transition by targeting Snail and is downregulated in non-small cell lung cancer. Int J Cancer 130: 2044-2053

178. Lin CW, Chang YL, Chang YC, Lin JC, Chen CC, Pan SH, Wu CT, Chen HY, Yang SC, Hong TM et al (2013) MicroRNA-135b promotes lung cancer metastasis by regulating multiple targets in the Hippo pathway and LZTS1. Nat Commun 4:1877

179. Yigit MV, Ghosh SK, Kumar M, Petkova V, Kavishwar A, Moore A, Medarova Z (2013) Context-dependent differences in miR-10b breast oncogenesis can be targeted for the prevention and arrest of lymph node metastasis. Oncogene 32:1530-1538

180. Penna E, Orso F, Cimino D, Vercellino I, Grassi E, Quaglino E, Turco E, Taverna D (2013) miR-214 coordinates melanoma progression by upregulating ALCAM through TFAP2 and miR-148b downmodulation. Cancer Res 73:4098-4111 